\title{
Proton-Assisted Hydration at Hydrophobic Sites in Protonated Ether and Keto Dimers
}

\author{
Ina Hahndorf, $\dagger$ Jyh-Chiang Jiang, Hai-Chou Chang, $\$$ Chi-Che Wu, and Huan-Cheng Chang* \\ Institute of Atomic and Molecular Sciences, Academia Sinica, P.O. Box 23-166, Taipei, Taiwan, R.O.C., and \\ Department of Chemistry, National Taiwan University, Taipei, Taiwan, R.O.C.
}

Received: June 7, 1999; In Final Form: August 30, 1999

\begin{abstract}
Charge-enhanced hydrophobic hydration is investigated for protonated hydrophobe-containing water clusters synthesized by a supersonic expansion. The investigation begins with clusters consisting of a protonated dimethyl ether dimer $\left[\left(\mathrm{CH}_{3}\right)_{2} \mathrm{O}_{2} \mathrm{H}^{+}\right.$and one water unit, which can be considered as the prototype of ionic hydrophobe-water systems. The methodologies involved in this investigation are vibrational predissociation spectroscopy and ab initio calculations based on density functional theory. The $\left[\left(\mathrm{CH}_{3}\right)_{2} \mathrm{O}\right]_{2} \mathrm{H}^{+}$ions are first synthesized by corona discharge of dimethyl ether $-\mathrm{H}_{2} \mathrm{O}$ mixtures seeded in a continuously operated $\mathrm{H}_{2}$ beam. Through supersonic expansion, the protonated hydrophobe $\left(\mathrm{CH}_{3}\right)_{2} \mathrm{O}-\mathrm{H}^{+}-\mathrm{O}\left(\mathrm{CH}_{3}\right)_{2}$ forms complexes with $\mathrm{H}_{2} \mathrm{O}$, leading to hydrophobic hydration. Two types of isomers, hydrophobic and $\mathrm{H}_{3} \mathrm{O}^{+}$-centered, are identified by a close examination of both hydrogen-bonded and non-hydrogen-bonded $\mathrm{OH}$ stretches of the solvent water molecules. The two isomers display distinctly different $\mathrm{OH}$ stretching spectra and, furthermore, a drastic change of the spectra with the variation of beam temperature. In this work, in addition to $\left[\left(\mathrm{CH}_{3}\right)_{2} \mathrm{O}\right]_{2} \mathrm{H}^{+-}$ $\mathrm{H}_{2} \mathrm{O}$, water clusters containing the hydrophobes of protonated methyl ethyl ether dimers $\left[\left(\mathrm{CH}_{3}\right)\left(\mathrm{C}_{2} \mathrm{H}_{5}\right) \mathrm{O}-\right.$ $\left.\mathrm{H}^{+}-\mathrm{O}\left(\mathrm{CH}_{3}\right)\left(\mathrm{C}_{2} \mathrm{H}_{5}\right)\right]$, protonated acetone dimers $\left[\left(\mathrm{CH}_{3}\right)_{2} \mathrm{CO}-\mathrm{H}^{+}-\mathrm{OC}\left(\mathrm{CH}_{3}\right)_{2}\right]$, and protonated acetaldehyde dimers $\left[\left(\mathrm{CH}_{3}\right) \mathrm{HCO}-\mathrm{H}^{+}-\mathrm{OCH}\left(\mathrm{CH}_{3}\right)\right]$ are also studied. These clusters together represent four test systems for the understanding of the nature of hydrophobic interactions in the unusual form of $-\mathrm{C}-\mathrm{H} \cdots \mathrm{O}-$.
\end{abstract}

\section{Introduction}

Hydrophobic interactions govern various essential reactions in chemical and biological systems. The complex and fascinating phenomena, such as protein folding, ${ }^{1}$ molecular recognition, ${ }^{2}$ and self-assembly in organic thin films, ${ }^{3}$ are all rooted in such weak intermolecular forces. To understand the nature of hydrophobic effects, ${ }^{4}$ particularly the hydrophobic hydration, studies of molecular clusters in the gas phase have been actively undertaken over the past 2 decades. ${ }^{5}$ The gas-phase study is advantageous over that of condensed phases in one important aspect: structures of the hydrophobe-water clusters can be systematically investigated by sequentially adding water molecules to the hydrophobe. The systematic investigation can reveal the microscopic details at varying stages of the hydration processes.

Some prior studies of hydrophobic hydration have explored a prototypical system, $\mathrm{CH}_{4}-\mathrm{H}_{2} \mathrm{O}$. Saykally and co-workers ${ }^{6}$ obtained the first vibration-rotation-tunneling absorption spectrum of this binary complex using a far-infrared laser and concluded that the complexation between $\mathrm{CH}_{4}$ and $\mathrm{H}_{2} \mathrm{O}$ is established by proton donation from the hydrogen atom of water to methane. Their results were later confirmed by Suenram et al. ${ }^{7}$ who found no evidence of $-\mathrm{C}-\mathrm{H} \cdots \mathrm{O}-$ interactions in their Fourier transform microwave spectroscopic measurements.

\footnotetext{
$\dagger$ Present address: Institut für Angewandte Chemie Adlershof, D-12484 Berlin, Germany.

$\doteqdot$ Present address: Department of Chemistry, Dong-Hwa University, HuaLien, Taiwan, R.O.C.
}

Calculations of the $\mathrm{CH}_{4}-\mathrm{H}_{2} \mathrm{O}$ interaction energy using a Lennard-Jones potential yielded a $D_{\mathrm{e}} \approx 0.25 \mathrm{kcal} / \mathrm{mol},{ }^{8}$ which is considerably lower than the strength $(\sim 5 \mathrm{kcal} / \mathrm{mol})$ of the hydrogen bonding between water molecules. ${ }^{9}$ For the more complicated dimer, $\mathrm{C}_{3} \mathrm{H}_{8}-\mathrm{H}_{2} \mathrm{O}$, although structural determination remains inclusive, ${ }^{10}$ an analysis of the far-infrared spectra implies that the hydrophobic interaction of this type $-\mathrm{C}-\mathrm{H} \cdot \cdot$ $\cdot \mathrm{O}-$ can exist via multiple hydrogen bond formation. Solid evidence for the existence of the direct $-\mathrm{C}-\mathrm{H} \cdots \mathrm{O}-$ bonding was first found in unsaturated hydrocarbon-water complexes where proton donation from such hydrocarbon to water is more accessible. In $\mathrm{C}_{2} \mathrm{H}_{2}-\mathrm{H}_{2} \mathrm{O}$, both microwave and infrared measurements revealed that the local $C_{2}$ axis of $\mathrm{H}_{2} \mathrm{O}$ is aligned collinear with the $A$ rotational axis of acetylene, which acts a proton donor. ${ }^{11}$ This finding, however, is not unexpected, since acetylene is a well-known Lewis acid and its bonding with water is markedly different in nature from that between saturated hydrocarbon and water molecules.

The hydrophobic $-\mathrm{C}-\mathrm{H} \cdots \mathrm{O}-$ interactions can be dramatically enhanced in the presence of charges. The charge-enhanced interactions give rise to a binding energy up to $10 \mathrm{kcal} / \mathrm{mol}$, which is twice as high as the dissociation energy $\left(\Delta H^{\circ}{ }_{\mathrm{D}}=3.59\right.$ $\mathrm{kcal} / \mathrm{mol}$ ) of the neutral water dimer. ${ }^{9}$ An earlier attempt made by Meot-Ner and Deakyne ${ }^{12}$ has investigated the hydrogen bonding between solvent water molecules and hydrophobic quaternary ions, such as $\mathrm{N}\left(\mathrm{CH}_{3}\right)_{4}{ }^{+}$and $\mathrm{N}\left(\mathrm{C}_{2} \mathrm{H}_{5}\right)_{4}{ }^{+}$. From thermochemical measurements of hydrogen bond enthalpies using a pulsed high-pressure mass spectrometer, an interaction 
energy of $9.0 \mathrm{kcal} / \mathrm{mol}$ between $\mathrm{N}\left(\mathrm{CH}_{3}\right)_{4}{ }^{+}$and $\mathrm{H}_{2} \mathrm{O}$ was determined. The bonding of the second water molecule to $\mathrm{N}\left(\mathrm{CH}_{3}\right)_{4}{ }^{+}-\mathrm{H}_{2} \mathrm{O}$ stays strong, with a $\Delta H^{\circ}{ }_{\mathrm{D}}=9.4 \mathrm{kcal} / \mathrm{mol}$. The authors further obtained information concerning the structures of the clusters from $a b$ initio calculations and predicted that the water molecule in $\mathrm{N}\left(\mathrm{CH}_{3}\right)_{4}{ }^{+}-\mathrm{H}_{2} \mathrm{O}$ prefers to attach electrostatically to a cavity created by protons of three $\mathrm{CH}_{3}$ groups rather than to be hydrogen-bonded to one proton or to one of the four methyl groups. The studies of these unconventional ionic hydrogen bonds are important from the perspective that they are directly correlated with the hydrophobicity of amino acids.

Correlations between the hydrophobicity of hydrocarbons and the structure of their hydration shells have been a subject of extensive investigations, both experimentally ${ }^{13}$ and theoretically, ${ }^{14}$ in condensed phases. Contemporary studies ${ }^{15,16}$ employed a variety of spectroscopic methods to investigate the structures of hydrogen-bonded hydration shells around the hydrophobic sites of amino acids. Compared to that of bulk water, an increase in hydrogen bonding, along with a decrease in entropy, between water molecules surrounding dissolved hydrocarbon molecules has been inferred from calorimetric measurements of molar heat capacity. ${ }^{17}$ A similar feature was revealed by Fourier transform infrared ${ }^{15}$ and Raman scattering ${ }^{16}$ spectra of ordered water layers over the hydrophobic side chains of amino acids. It has, however, been noted that amino acids in solution phases are mostly charged in positive, negative, or zwitterionic forms; hence, the nature of the charge-supported hydrophobic hydration could be markedly different from that inferred from the hydrophobicity measurements concerning the solubility of hydrocarbons in water and the partition coefficients of various solutes between aqueous and nonpolar phases. ${ }^{15}$ The question of how a charge can alter the hydrophobicity of amino acid side chains remains open and awaits to be addressed.

Vibrational spectroscopy of valence bond stretches has been a powerful technique for elucidating the nature of hydrogenbonded ionic species in both gaseous and condensed phases. In this study, we systematically monitor the vibrational spectra of the free-OH and hydrogen-bonded $\mathrm{OH}$ stretches of hydrated cluster ions as a function of structure, particle size, and internal temperature. Adjoined with ab initio calculations, this experimental endeavor provides useful information concerning the interactions between water and the hydrophobic sites of chargecarrying molecules. The charge-enhanced hydrophobic hydration in clusters consisting of a protonated hydrophobe and one single water molecule is the focus of the present examination. The hydrophobes to be closely examined are the protonated dimethyl ether dimer $\left[\left(\mathrm{CH}_{3}\right)_{2} \mathrm{O}-\mathrm{H}^{+}-\mathrm{O}\left(\mathrm{CH}_{3}\right)_{2}\right]$, the protonated methyl ethyl ether dimer $\left[\left(\mathrm{CH}_{3}\right)\left(\mathrm{C}_{2} \mathrm{H}_{5}\right) \mathrm{O}-\mathrm{H}^{+}-\mathrm{O}\left(\mathrm{CH}_{3}\right)\left(\mathrm{C}_{2} \mathrm{H}_{5}\right)\right]$, the protonated acetone dimer $\left[\left(\mathrm{CH}_{3}\right)_{2} \mathrm{CO}-\mathrm{H}^{+}-\mathrm{OC}\left(\mathrm{CH}_{3}\right)_{2}\right]$, and the protonated acetaldehyde dimer $\left[\left(\mathrm{CH}_{3}\right) \mathrm{HCO}-\mathrm{H}^{+}-\mathrm{OCH}\left(\mathrm{CH}_{3}\right)\right]$. This fundamental study of charge-supported hydrophobic interactions is expected to be biologically significant, since the solvation and folding of peptides or proteins in water largely involve ionic hydrogen bonding. Successful studies of these model cluster systems should provide a solid basis for future investigation of more complex reactions, such as the hydration of amino acids, in the gas phase.

\section{Methods}

A. Vibrational Predissociation Spectroscopy. An integrated system $^{18}$ of a tandem mass ion trap spectrometer and a pulsed infrared laser is employed to obtain the $\mathrm{OH}$ stretching spectra of water clusters containing protonated ether or keto dimers, denoted as $\mathrm{H}^{+} \mathrm{B}_{2}\left(\mathrm{H}_{2} \mathrm{O}\right)_{n}$. The investigation starts with the hydrophobe, $\left[\left(\mathrm{CH}_{3}\right)_{2} \mathrm{O}-\mathrm{H}^{+}-\mathrm{O}\left(\mathrm{CH}_{3}\right)_{2}\right]$, which is synthesized from ionization of a mixture of dimethyl ether-water $-\mathrm{H}_{2}$ in a corona discharge ion source. Hydrophobic hydration is established by a supersonic jet expansion of the gaseous mixture through a $75 \mu \mathrm{m}$ nozzle to form protonated dimethyl etherwater clusters. The jet-synthesized clusters, after size selection by a sector magnet mass spectrometer, are injected into a radio frequency $(\mathrm{RF})$ octopole ion trap for temperature measurements. ${ }^{18,19}$ The typical internal temperature of these clusters is estimated to be around $170 \mathrm{~K}$, which can be varied over the range of $\pm 30 \mathrm{~K}$ by properly adjusting the nozzle temperature and beam expansion conditions. Inside the RF trap, irradiating the size-selected cluster ions with resonant infrared photons induces a unimolecular dissociation as

$$
\mathrm{H}^{+} \mathrm{B}_{2}\left(\mathrm{H}_{2} \mathrm{O}\right)_{n}+h v \rightarrow \mathrm{H}^{+} \mathrm{B}_{2}\left(\mathrm{H}_{2} \mathrm{O}\right)_{n-1}+\mathrm{H}_{2} \mathrm{O}
$$

Vibrational predissociation spectra of both non-hydrogen-bonded (free) and hydrogen-bonded $\mathrm{OH}$ stretches of $\mathrm{H}^{+} \mathrm{B}_{2}\left(\mathrm{H}_{2} \mathrm{O}\right)_{n}$ are obtained by counting the number of $\mathrm{H}^{+} \mathrm{B}_{2}\left(\mathrm{H}_{2} \mathrm{O}\right)_{n-1}$ generated as a function of laser frequency.

B. Ab Initio Calculations. The ab initio calculations for $\mathrm{H}^{+} \mathrm{B}_{2}\left(\mathrm{H}_{2} \mathrm{O}\right)_{n}$ are carried out using the commercial program package GAUSSIAN 94. ${ }^{20}$ All the computational results presented in this article are obtained based on density functional theory (DFT) with the Becke3LYP functional and the $6-31+\mathrm{G}^{*}$ basis set. This combination of method and basis set has been successfully applied to neutral benzene-water clusters ${ }^{21}$ and ammonia hydrate clusters ${ }^{22}$ before. We optimize the geometries of the clusters of interest using analytical gradients and obtain the harmonic vibrational frequencies using analytical second derivatives for various isomers. The structural optimizations are symmetry-unconstrained with the binding energies corrected by zero-point vibrational energy (ZPVE) and basis set superposition errors (BSSE) following the procedures suggested by Boys and Bernardi. ${ }^{23}$ The calculated total energies of the clustering

$$
\mathrm{H}^{+} \mathrm{B}_{2}+\mathrm{H}_{2} \mathrm{O} \rightarrow \mathrm{H}_{3} \mathrm{O}^{+}-\mathrm{B}_{2}
$$

or

$$
\mathrm{H}^{+} \mathrm{B}_{2}+\mathrm{H}_{2} \mathrm{O} \rightarrow \mathrm{H}^{+} \mathrm{B}_{2}-\mathrm{H}_{2} \mathrm{O}
$$

are compared to experimental values to ensure the validity of the computation. The calculated vibrational frequencies are scaled by a single factor $(\times 0.973)$ with respect to the free-OH stretches of two- and three-coordinated $\mathrm{H}_{2} \mathrm{O}$ in protonated water clusters. ${ }^{24}$

\section{Previous Studies}

Important thermochemical measurements have been previously made for protonated dimethyl ether-water mixed clusters. Kebarle and co-workers ${ }^{25}$ studied the temperature dependence of the equilibrium constants for reactions involving successive addition of water or dimethyl ether molecules to protonated cluster dimers. The determined enthalpies for the addition reactions are

$$
\begin{array}{r}
\mathrm{H}^{+}\left[\left(\mathrm{CH}_{3}\right)_{2} \mathrm{O}\right]_{2}+\mathrm{H}_{2} \mathrm{O} \rightarrow \mathrm{H}^{+}\left[\left(\mathrm{CH}_{3}\right)_{2} \mathrm{O}\right]_{2}\left(\mathrm{H}_{2} \mathrm{O}\right), \\
\Delta H^{\circ}=-16.3 \mathrm{kcal} / \mathrm{mol}
\end{array}
$$




$$
\begin{aligned}
&\left(\mathrm{CH}_{3}\right)_{2} \mathrm{OH}^{+}-\mathrm{H}_{2} \mathrm{O}+\left(\mathrm{CH}_{3}\right)_{2} \mathrm{O} \rightarrow \mathrm{H}^{+}\left[\left(\mathrm{CH}_{3}\right)_{2} \mathrm{O}\right]_{2}\left(\mathrm{H}_{2} \mathrm{O}\right), \\
& \Delta H^{\circ}=-18.5 \mathrm{kcal} / \mathrm{mol}
\end{aligned}
$$

indicating that a relatively higher energy is required to induce the unimolecular loss of $\left(\mathrm{CH}_{3}\right)_{2} \mathrm{O}$ instead of the loss of $\mathrm{H}_{2} \mathrm{O}$ when exciting $\mathrm{H}^{+}\left[\left(\mathrm{CH}_{3}\right)_{2} \mathrm{O}\right]_{2}\left(\mathrm{H}_{2} \mathrm{O}\right)$. This is in line with the finding that the proton affinity of dimethyl ether exceeds that of water by $24 \mathrm{kcal} / \mathrm{mol}^{26}$ and with the result of our metastable dissociation measurements that the water loss channel of $\mathrm{H}^{+}$$\left[\left(\mathrm{CH}_{3}\right)_{2} \mathrm{O}\right]_{2}\left(\mathrm{H}_{2} \mathrm{O}\right)$ is about 4 orders of magnitude more accessible than the ether loss channel at the cluster temperature of $170 \mathrm{~K}$. While the thermochemical measurements reveal useful information about bond strengths, they furnish little knowledge concerning the structure of the cluster isomers created in the highpressure mass spectrometers. ${ }^{27}$

Graul and Squires ${ }^{28}$ deduced the structural information on $\mathrm{H}^{+}\left[\left(\mathrm{CH}_{3}\right)_{2} \mathrm{O}\right]_{m}\left(\mathrm{H}_{2} \mathrm{O}\right)_{n}$ from collision-induced dissociation studies of these clusters in a flowing afterglow mass spectrometer. On the basis of preferential loss of the ether, they concluded that a hydronium ion must be the center of the mixed dimethyl etherwater clusters. A similar conclusion was reached by Schindler et al. ${ }^{29}$ who found exceptionally stable $\mathrm{H}^{+}\left[\left(\mathrm{C}_{2} \mathrm{H}_{5}\right)_{2} \mathrm{O}\right]_{m}\left(\mathrm{H}_{2} \mathrm{O}\right)_{n}$ clusters appearing at the solvation number of $m=n+2$. The finding of these "magic" numbers was attributed to the presence of the hydrophobic ethyl groups, which can effectively block hydrogen bonding. No evidence, however, was yet provided for the existence of hydrophobic isomers by these studies.

Theoretical calculations, meanwhile, examined the geometry of a system closely resembling the protonated dimethyl etherwater clusters: $\mathrm{H}^{+}\left[\left(\mathrm{CH}_{3}\right)_{2} \mathrm{O}\right]_{n}$. Hirao et al. ${ }^{30}$ investigated the dimethyl ether dimer and predicted that the excess proton in this cluster is located between two monomer units in a symmetric manner. A third dimethyl ether molecule can approach this binary complex at a long distance, forming a stable trimer by the $-\mathrm{C}-\mathrm{H} \cdots \mathrm{O}-$ linkage. Such an unconventional hydrogen bond has an experimentally determined bond strength of $\Delta H^{\circ}{ }_{\mathrm{D}}=10.1 \mathrm{kcal} / \mathrm{mol}^{25}$ This strength, comparable to that of $\mathrm{N}\left(\mathrm{CH}_{3}\right)_{4}{ }^{+}-\mathrm{H}_{2} \mathrm{O}$, is remarkably enhanced because of electrostatic forces.

The other system that has been actively studied in the past is the mixed acetone-water clusters, $\mathrm{H}^{+}\left[\left(\mathrm{CH}_{3}\right)_{2} \mathrm{CO}\right]_{m}\left(\mathrm{H}_{2} \mathrm{O}\right)_{n} .{ }^{31}$ The thermochemical data readily available in the literature $\operatorname{are}^{32}$

$$
\begin{array}{r}
\mathrm{H}^{+}\left[\left(\mathrm{CH}_{3}\right)_{2} \mathrm{CO}\right]_{2}+\mathrm{H}_{2} \mathrm{O} \rightarrow \mathrm{H}^{+}\left[\left(\mathrm{CH}_{3}\right)_{2} \mathrm{CO}\right]_{2}\left(\mathrm{H}_{2} \mathrm{O}\right), \\
\Delta H^{\circ}=-11.7 \mathrm{kcal} / \mathrm{mol}
\end{array}
$$

and

$$
\begin{array}{r}
\left(\mathrm{CH}_{3}\right)_{2} \mathrm{COH}^{+}-\mathrm{H}_{2} \mathrm{O}+\left(\mathrm{CH}_{3}\right)_{2} \mathrm{CO} \rightarrow \mathrm{H}^{+}\left[\left(\mathrm{CH}_{3}\right)_{2} \mathrm{CO}\right]_{2}\left(\mathrm{H}_{2} \mathrm{O}\right), \\
\Delta H^{\circ}=-21.2 \mathrm{kcal} / \mathrm{mol}(7)
\end{array}
$$

Again, from time-of-flight measurements of metastable unimolecular and collision-induced dissociation of $\mathrm{H}^{+}\left[\left(\mathrm{CH}_{3}\right)_{2} \mathrm{CO}\right]_{2}-$ $\left(\mathrm{H}_{2} \mathrm{O}\right)$, only a hydronium-centered structure was inferred for this cluster. ${ }^{31}$

\section{Results and Analysis}

The vibrational predissociation spectra showing the $\mathrm{OH}$ stretching modes of $\mathrm{H}^{+}\left[\left(\mathrm{CH}_{3}\right)_{2} \mathrm{O}\right]_{2}\left(\mathrm{H}_{2} \mathrm{O}\right)$ within the frequency range $3300-3800 \mathrm{~cm}^{-1}$ are given in Figure 1. A simple temperature-dependence measurement revealed a drastic change in the spectrum of free-OH stretches. In line with previous assignments for protonated water clusters, ${ }^{33,34}$ the bands at 3635 and $3719 \mathrm{~cm}^{-1}$ are ascribed, respectively, to the symmetric and
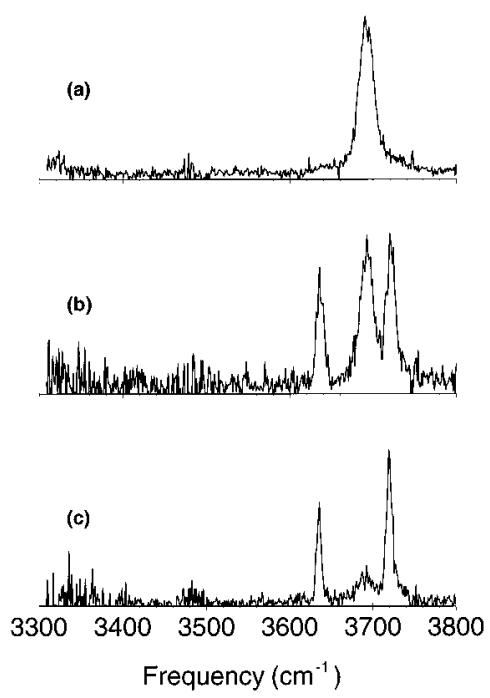

Figure 1. Vibrational predissociation spectra of $\mathrm{H}^{+}\left[\left(\mathrm{CH}_{3}\right)_{2} \mathrm{O}\right]_{2}\left(\mathrm{H}_{2} \mathrm{O}\right)$ synthesized using a room-temperature nozzle with a backing pressure of (a) 60, (b) 160, and (c) 260 Torr, respectively. The corresponding internal temperatures of the clusters are roughly (a) 200, (b) 170, and (c) $150 \mathrm{~K}$. The dramatic temperature dependence of the spectra indicates the presence of more than one stable isomer in the supersonic jet.
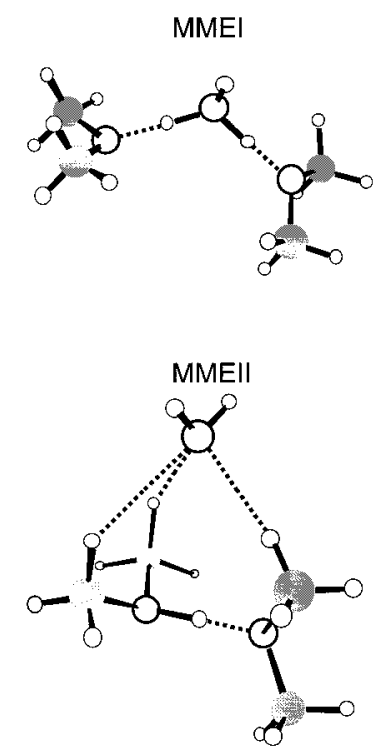

Figure 2. DFT-optimized structures of $\mathrm{H}^{+}\left[\left(\mathrm{CH}_{3}\right)_{2} \mathrm{O}\right]_{2}\left(\mathrm{H}_{2} \mathrm{O}\right)$. The $\mathrm{C}$, $\mathrm{O}$, and $\mathrm{H}$ atoms are denoted by gray solid, large open and small open circles, respectively.

asymmetric free-OH stretches of the proton-accepting water molecule in the first solvation shell $\left(1^{\circ}\right)$, and the band at 3690 $\mathrm{cm}^{-1}$ represents the free-OH stretching mode of the twocoordinated $\mathrm{H}_{3} \mathrm{O}^{+}$ion core. The independent changes of the absorption band intensities with cluster temperature clearly indicate that these three bands are derived from two structurally different isomers. ${ }^{18}$ In obtaining these three spectra (Figure 1), we varied the cluster temperature only roughly from 150 to 200 $\mathrm{K}$, but the effect is dramatic. The origin of this dramatic effect within such a small temperature range will be thoroughly discussed in a later section.

$\mathrm{Ab}$ initio calculations performed at the $\mathrm{B} 3 \mathrm{LYP} / 6-31+\mathrm{G}^{*}$ level yielded two optimized geometries for the $\mathrm{H}^{+}\left[\left(\mathrm{CH}_{3}\right)_{2} \mathrm{O}\right]_{2}\left(\mathrm{H}_{2} \mathrm{O}\right)$ cluster (cf. Figure 2). Figure 3 compares the calculated stick diagrams of these two isomers, denoted as MMEI (or $\mathrm{H}_{3} \mathrm{O}^{+}$$\left.\left[\left(\mathrm{CH}_{3}\right)_{2} \mathrm{O}\right]_{2}\right)$ and MMEII (or $\left[\left(\mathrm{CH}_{3}\right)_{2} \mathrm{O}_{2} \mathrm{H}^{+}-\mathrm{H}_{2} \mathrm{O}\right.$ ), with the experimental spectra. Both isomers display spectral features to 
TABLE 1: Ab Initio Calculated Energies (kcal/mol) of the Clustering via Channel I, $\mathrm{B}_{2} \mathrm{H}^{+}+\mathrm{H}_{2} \mathrm{O} \rightarrow \mathrm{H}_{3} \mathrm{O}^{+}-\mathrm{B}_{2}$, or $\mathrm{Channel}_{\mathrm{II}}$, $\mathrm{B}_{2} \mathrm{H}^{+}+\mathrm{H}_{2} \mathrm{O} \rightarrow \mathrm{B}_{2} \mathrm{H}^{+}-\mathrm{H}_{2} \mathrm{O}$, Where $\mathrm{B}=\left(\mathrm{CH}_{3}\right)_{2} \mathrm{O},\left(\mathrm{CH}_{3}\right)\left(\mathrm{C}_{2} \mathrm{H}_{5}\right) \mathrm{O},\left(\mathrm{CH}_{3}\right)_{2} \mathrm{CO}$, or $\left(\mathrm{CH}_{3}\right) \mathrm{HCO}$, at $298 \mathrm{~K}^{a}$

\begin{tabular}{|c|c|c|c|c|}
\hline species & isomers $^{b}$ & $\Delta E^{c}$ & $\Delta H^{298 c}$ & $\Delta G^{298 c}$ \\
\hline \multirow[t]{2}{*}{$\mathrm{H}^{+}\left[\left(\mathrm{CH}_{3}\right)_{2} \mathrm{O}\right]_{2}\left(\mathrm{H}_{2} \mathrm{O}\right)$} & MMEI & $-11.3(-10.7)$ & $-12.2(-11.4)$ & $-3.2(-3.1)$ \\
\hline & MMEII & $-6.2(-5.8)$ & $-6.5(-5.8)$ & $+2.4(+2.0)$ \\
\hline \multirow[t]{3}{*}{$\mathrm{H}^{+}\left[\left(\mathrm{CH}_{3}\right)\left(\mathrm{C}_{2} \mathrm{H}_{5}\right) \mathrm{O}\right]_{2}\left(\mathrm{H}_{2} \mathrm{O}\right)$} & MEEI & -11.0 & -11.6 & -4.3 \\
\hline & MEEII & -6.4 & -6.5 & +1.5 \\
\hline & MEEIII & -6.2 & -6.2 & +0.9 \\
\hline \multirow[t]{3}{*}{$\mathrm{H}^{+}\left[\left(\mathrm{CH}_{3}\right)_{2} \mathrm{CO}\right]\left(\mathrm{H}_{2} \mathrm{O}\right)$} & ATI & -10.0 & -9.9 & -2.2 \\
\hline & ATII & -5.8 & -5.8 & +1.7 \\
\hline & ATIII & -3.8 & -3.9 & +4.1 \\
\hline \multirow[t]{5}{*}{$\mathrm{H}^{+}\left[\left(\mathrm{CH}_{3}\right) \mathrm{HCO}\right]_{2}\left(\mathrm{H}_{2} \mathrm{O}\right)$} & AAI & -9.4 & -10.3 & -2.2 \\
\hline & AAII & -6.8 & -6.9 & +1.0 \\
\hline & AAIII & -6.0 & -6.2 & +2.3 \\
\hline & AAIV & -6.6 & -6.5 & +0.5 \\
\hline & AAV & -4.2 & -3.9 & +1.8 \\
\hline
\end{tabular}

${ }^{a}$ Calculated using B3LYP/6-31+G*. $\Delta E$ represents the interaction energy with both basis set superposition errors and zero-point vibrational energies corrected. ${ }^{b}$ Structures illustrated in Figures 2, 6, 9, and 10. ${ }^{c}$ The numbers in parentheses are those calculated using B3LYP/aug-cc-pVDZ.
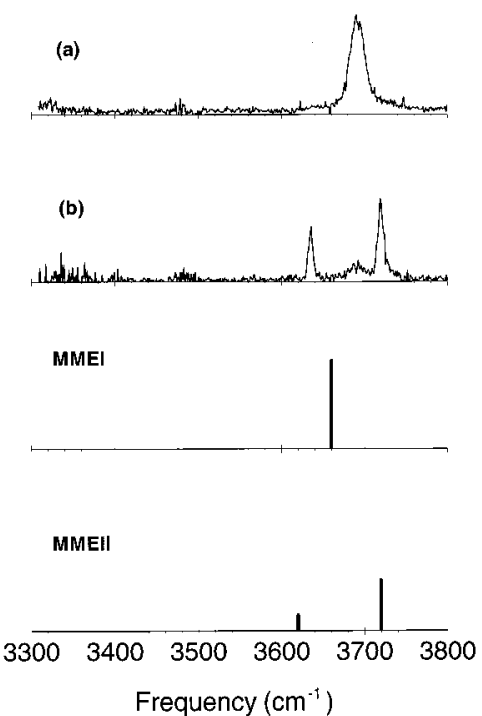

Figure 3. Comparison of the vibrational predissociation spectra with the DFT-calculated stick diagrams of $\mathrm{H}^{+}\left[\left(\mathrm{CH}_{3}\right)_{2} \mathrm{O}\right]_{2}\left(\mathrm{H}_{2} \mathrm{O}\right)$ for both isomers MMEI and MMEII.

be in good agreement with the observations in the frequency range $3300-3800 \mathrm{~cm}^{-1}$. Notably, isomer MMEI is $\mathrm{H}_{3} \mathrm{O}^{+}$centered and its subunits are linked by two conventional $-\mathrm{C}-$ $\mathrm{O} \cdot \cdot \mathrm{H}-\mathrm{O}-$ hydrogen bonds, whereas MMEII is $\mathrm{H}^{+}$-centered and its subunits are held together by charge-enhanced hydrophobic forces such as $-\mathrm{C}-\mathrm{H} \cdots \mathrm{O}-$. The theoretically predicted interaction energies $(\Delta E)$ between $\left[\left(\mathrm{CH}_{3}\right)_{2} \mathrm{O}\right]_{2} \mathrm{H}^{+}$and $\mathrm{H}_{2} \mathrm{O}$ to form isomers MMEI and MMEII are -11.3 and $-6.2 \mathrm{kcal} /$ mol, respectively (Table 1); hence, the $\mathrm{H}_{3} \mathrm{O}^{+}$-centered form is more strongly bound than the hydrophobic one by about $5 \mathrm{kcal} /$ mol. It is important to emphasize here that such $-\mathrm{C}-\mathrm{H} \cdots \mathrm{O}-$ interactions, while involving multiple bond formation between $\mathrm{H}$ and $\mathrm{O}$ (Figure 2), should not be characterized in terms of conventional hydrogen bonding, since no significant donation of the lone-pair electrons from the oxygen to the hydrogen atom occurs. Similar to that of $\mathrm{N}\left(\mathrm{CH}_{3}\right)_{4}{ }^{+}-\mathrm{H}_{2} \mathrm{O},{ }^{12}$ the intermolecular interactions are purely electrostatic, dominated by charge-dipole forces.

In comparison to the experimentally measured hydration enthalpy of $-\Delta H^{\circ}(298)=16.3 \mathrm{kcal} / \mathrm{mol}$ in eq $4,{ }^{25}$ the calculated values of $-\Delta H^{298}=12.2$ and $6.5 \mathrm{kcal} / \mathrm{mol}$ in Table 1 are both significantly underestimated. It leads us to use a larger and more polarizable basis set, aug-cc-pVDZ, ${ }^{35}$ in the calculations. However, a result essentially identical to that of B3LYP/6-
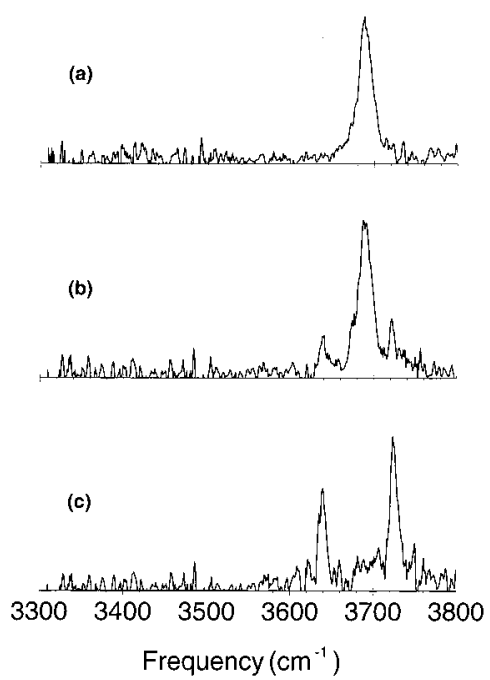

Figure 4. Vibrational predissociation spectra of $\mathrm{H}^{+}\left[\left(\mathrm{CH}_{3}\right)\left(\mathrm{C}_{2} \mathrm{H}_{5}\right) \mathrm{O}_{2}-\right.$ $\left(\mathrm{H}_{2} \mathrm{O}\right)$ synthesized using a room-temperature nozzle with a backing pressure of (a) 50, (b) 80, and (c) 120 Torr, respectively. The dramatic temperature dependence of the spectra indicates the presence of more than one stable isomer in the supersonic jet.

$31+\mathrm{G}^{*}$ was obtained, with $-\Delta H^{298}=11.4 \mathrm{kcal} / \mathrm{mol}$ for MMEI and $5.8 \mathrm{kcal} / \mathrm{mol}$ for MMEII (Table 1). An independent calculation using the MP2 method and the $6-31+\mathrm{G}^{*}$ basis set was further applied to MMEI. It yields a hydration enthalpy of $-\Delta H^{298}=10.0 \mathrm{kcal} / \mathrm{mol}$, even smaller than the DFT-calculated value. At present, the origin of this large discrepancy ( $>4 \mathrm{kcal} /$ $\mathrm{mol}$ ) between theory and experiment is unclear, but it does imply that a remeasurement of the hydration enthalpy is needed to resolve the difference. Despite being significantly underestimated, the calculated hydration enthalpy of $\Delta H^{298} \approx-12 \mathrm{kcal} /$ mol for isomer MMEI agrees quantitatively well with the measurement, corroborating the suggestion that the structure of $\mathrm{H}^{+}\left[\left(\mathrm{CH}_{3}\right)_{2} \mathrm{O}\right]_{2}\left(\mathrm{H}_{2} \mathrm{O}\right)$ existing under thermochemical equilibrium conditions is predominantly hydronium-centered at room temperature.

An attempt was also made to observe the bonded-OH stretches of isomer MMEI. The frequencies of these vibrations, however, are all much red-shifted and they fall in a region below $2700 \mathrm{~cm}^{-1}$, which is inaccessible using the present laser system. We conclude from the spectral comparison in Figure 3 that two structurally different cluster isomers have been synthesized by the corona-discharged supersonic expansion and are successfully transported to the octopole ion trap detection region. Table 2 gives the detailed assignments of these three absorption bands, 
TABLE 2: Frequencies, Width $\left(\mathrm{cm}^{-1}\right)$, and Assignments of the OH Stretching Features of $\mathrm{H}_{3} \mathrm{O}^{+}-\mathrm{B}_{2}$ or $\mathrm{B}_{2} \mathrm{H}^{+}-\mathrm{H}_{2} \mathrm{O}$, Where $\mathrm{B}$ $=\left(\mathrm{CH}_{3}\right)_{2} \mathrm{O},\left(\mathrm{CH}_{3}\right)\left(\mathrm{C}_{2} \mathrm{H}_{5}\right) \mathrm{O},\left(\mathrm{CH}_{3}\right)_{2} \mathrm{CO}$, or $\left(\mathrm{CH}_{3}\right) \mathrm{HCO}$

\begin{tabular}{|c|c|c|c|c|}
\hline species & frequency $^{a}$ & $\mathrm{fwhm}^{b}$ & isomers $^{c}$ & assignments \\
\hline \multirow[t]{3}{*}{$\mathrm{H}^{+}\left[\left(\mathrm{CH}_{3}\right)_{2} \mathrm{O}\right]_{2}\left(\mathrm{H}_{2} \mathrm{O}\right)$} & 3719 & 7 & MMEII & asymmetric free- $\mathrm{OH}$ of $1^{\circ} \mathrm{H}_{2} \mathrm{O}$ \\
\hline & 3690 & 19 & MMEI & free-OH of $\mathrm{H}_{3} \mathrm{O}^{+}$ \\
\hline & 3635 & 5 & MMEII & symmetric free- $\mathrm{OH}$ of $1^{\circ} \mathrm{H}_{2} \mathrm{O}$ \\
\hline \multirow{3}{*}{$\mathrm{H}^{+}\left[\left(\mathrm{CH}_{3}\right)\left(\mathrm{C}_{2} \mathrm{H}_{5}\right) \mathrm{O}\right]_{2}\left(\mathrm{H}_{2} \mathrm{O}\right)$} & 3723 & 13 & MEEII, MEEIII & asymmetric free- $\mathrm{OH}$ of $1^{\circ} \mathrm{H}_{2} \mathrm{O}$ \\
\hline & 3688 & 18 & MEEI & free- $\mathrm{OH}$ of $\mathrm{H}_{3} \mathrm{O}^{+}$ \\
\hline & 3639 & 10 & MEEII, MEEIII & symmetric free- $\mathrm{OH}$ of $1^{\circ} \mathrm{H}_{2} \mathrm{O}$ \\
\hline \multirow[t]{3}{*}{$\mathrm{H}^{+}\left[\left(\mathrm{CH}_{3}\right)_{2} \mathrm{CO}\right]_{2}\left(\mathrm{H}_{2} \mathrm{O}\right)$} & 3723 & 9 & ATII & asymmetric free- $\mathrm{OH}$ of $1^{\circ} \mathrm{H}_{2} \mathrm{O}$ \\
\hline & 3668 & 31 & ATI & free- $\mathrm{OH}$ of $\mathrm{H}_{3} \mathrm{O}^{+}$ \\
\hline & 3640 & 7 & ATII & symmetric free- $\mathrm{OH}$ of $1^{\circ} \mathrm{H}_{2} \mathrm{O}$ \\
\hline \multirow[t]{3}{*}{$\mathrm{H}^{+}\left[\left(\mathrm{CH}_{3}\right) \mathrm{HCO}\right]_{2}\left(\mathrm{H}_{2} \mathrm{O}\right)$} & 3723 & 7 & AAII, AAIV & asymmetric free- $\mathrm{OH}$ of $1^{\circ} \mathrm{H}_{2} \mathrm{O}$ \\
\hline & 3663 & 27 & AAI & free- $\mathrm{OH}$ of $\mathrm{H}_{3} \mathrm{O}^{+}$ \\
\hline & 3638 & 5 & AAII, AAIV & symmetric free- $\mathrm{OH}$ of $1^{\circ} \mathrm{H}_{2} \mathrm{O}$ \\
\hline
\end{tabular}

${ }^{a}$ Uncertainty in frequency measurements is $\pm 1 \mathrm{~cm}^{-1} \cdot{ }^{b}$ Full width at half-maximum (fwhm). ${ }^{c}$ Structures of the isomers are illustrated in Figures 2, 6, 9 and 10 .

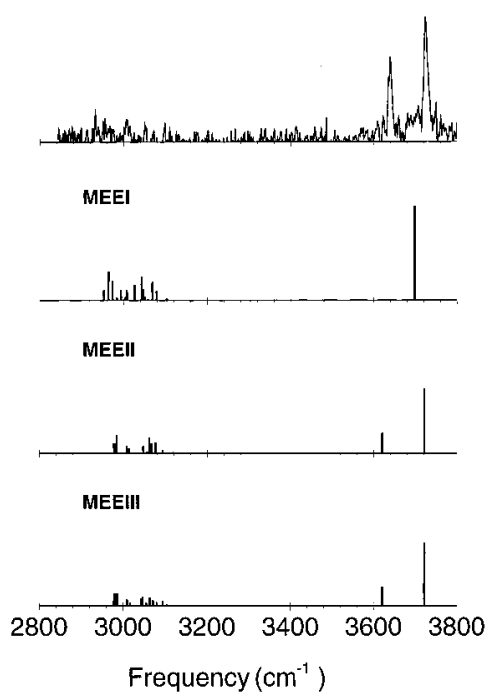

Figure 5. Comparison of the vibrational predissociation spectrum of cold $\mathrm{H}^{+}\left[\left(\mathrm{CH}_{3}\right)\left(\mathrm{C}_{2} \mathrm{H}_{5}\right) \mathrm{O}\right]_{2}\left(\mathrm{H}_{2} \mathrm{O}\right)$ cluster ions with the DFT-calculated stick diagrams of isomers MEEI, MEEII, and MEEIII. The weak features appearing at $2900-3100 \mathrm{~cm}^{-1}$ can be attributed to the $\mathrm{CH}$ stretches of isomer MEEII. Note that, according to the calculations, there is no significant enhancement in the absorption strength of the bonded-CH stretches of both isomers MEEII and MEEIII.

with the corresponding structures of the two low-energy isomers depicted in Figure 2. ${ }^{36}$

As a comparable case, the experimental spectra, calculated structures, and predicted stick diagrams of protonated methyl ethyl ether-water clusters $\left[\mathrm{H}^{+}\left[\left(\mathrm{CH}_{3}\right)\left(\mathrm{C}_{2} \mathrm{H}_{5}\right) \mathrm{O}_{2}\left(\mathrm{H}_{2} \mathrm{O}\right)\right]\right.$ are obtained and shown in Figures 4-6. The temperature-dependent spectra (Figure 4) of this cluster, bearing similarities to those of $\mathrm{H}^{+}\left[\left(\mathrm{CH}_{3}\right)_{2} \mathrm{O}_{2}{ }^{+}\left(\mathrm{H}_{2} \mathrm{O}\right)\right.$, also reveal that at least two types of stable isomers prevail in the supersonic jet. The B3LYP/6$31+\mathrm{G}^{*}$ calculations predict the existence of three low-energy isomers, denoted as MEEI, MEEII, and MEEIII in Figure 6. Among these three isomers, the $\mathrm{H}_{3} \mathrm{O}^{+}$-centered MEEI is most strongly bound, containing two normal $-\mathrm{C}-\mathrm{O} \cdots \mathrm{H}-\mathrm{O}-$ bonds, whereas both MEEII and MEEIII are $\mathrm{H}^{+}$-centered and their formation is made possible by the unconventional protonenhanced bonding, $-\mathrm{C}-\mathrm{H} \cdots \mathrm{O}-$. Interestingly, isomer MEEII is only slightly lower in energy (by $0.2 \mathrm{kcal} / \mathrm{mol}$ ) than MEEIII, which involves the bonding to two ethyl groups rather than to two methyl groups. According to this calculation, it is likely that both MEEII and MEEIII, in addition to MEEI, are present in the supersonic beam. A scan of the laser to the bonded- $\mathrm{CH}$ stretching region was made to distinguish these two types of hydrophobic isomer. Unfortunately, such $\mathrm{CH}$ stretching absorp-
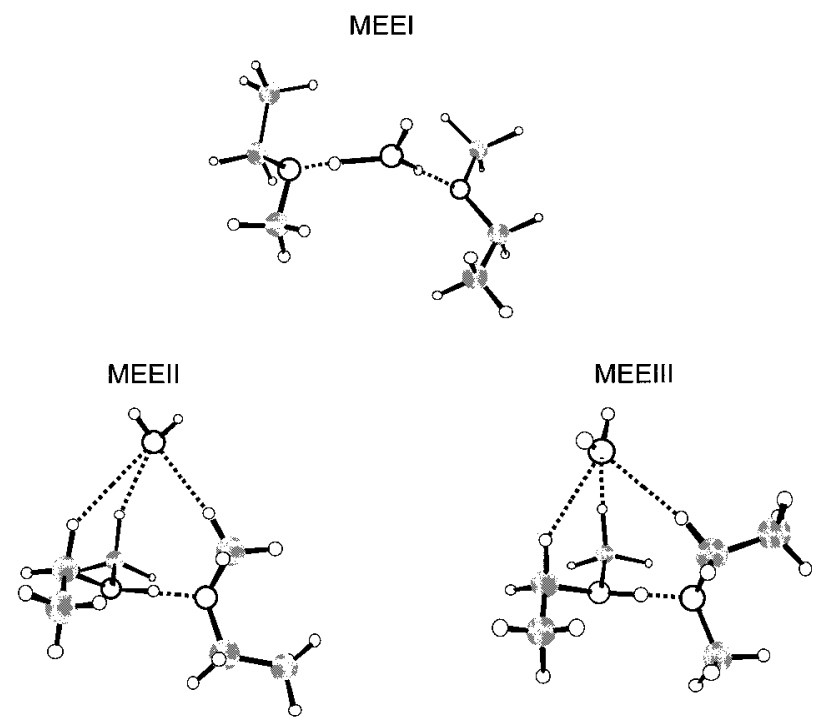

Figure 6. DFT-optimized structures of $\mathrm{H}^{+}\left[\left(\mathrm{CH}_{3}\right)\left(\mathrm{C}_{2} \mathrm{H}_{5}\right) \mathrm{O}\right]_{2}\left(\mathrm{H}_{2} \mathrm{O}\right)$ isomers. The $\mathrm{C}, \mathrm{O}$, and $\mathrm{H}$ atoms are denoted by gray solid, large open and small open circles, respectively.

tion bands centered at around $3000 \mathrm{~cm}^{-1}$ cannot be clearly detected (Figure 5), thereby disallowing unambiguous identification of them. Tables 1 and 2 list, respectively, the calculated relative energies of these three isomers and assignments of the observed vibrational features.

To develop further insight into how the behaviors of hydrophobic hydration change with the functional groups of the hydrophobes, the present investigation is extended to the studies of protonated keto-water clusters. Vibrational predissociation spectra of the water clusters containing protonated acetone dimers $\left[\left(\mathrm{CH}_{3}\right)_{2} \mathrm{CO}-\mathrm{H}^{+}-\mathrm{OC}\left(\mathrm{CH}_{3}\right)_{2}\right]$ and protonated acetaldehyde dimers $\left[\left(\mathrm{CH}_{3}\right) \mathrm{HCO}-\mathrm{H}^{+}-\mathrm{OCH}\left(\mathrm{CH}_{3}\right)\right]$ as the hydrophobes are displayed in Figures 7 and 8. They are compared systematically with the stick diagrams of various DFT-calculated isomers whose structures are depicted in Figures 9 and 10. For the hydronium-centered forms, they can be clearly identified from the characteristic free-OH stretching absorption at 3668 and $3663 \mathrm{~cm}^{-1}$ for isomers ATI and AAI, respectively. Structural identification of the hydrophobic isomers, however, is complicated by the presence of more than one stable isomeric form. This is particularly true for the protonated acetaldehyde hydrates, where more than three stable $\left[\left(\mathrm{CH}_{3}\right) \mathrm{HCO}_{2} \mathrm{H}^{+}-\mathrm{H}_{2} \mathrm{O}\right.$ isomers are found and, furthermore, they are comparable in stability. On the basis of the calculated energetics in Table 1, an assignment of the observed spectral features of $\left[\left(\mathrm{CH}_{3}\right)_{2}-\right.$ $\mathrm{CO}]_{2} \mathrm{H}^{+}-\mathrm{H}_{2} \mathrm{O}$ and $\left[\left(\mathrm{CH}_{3}\right) \mathrm{HCO}_{2} \mathrm{H}^{+}-\mathrm{H}_{2} \mathrm{O}\right.$ is suggested in Table 

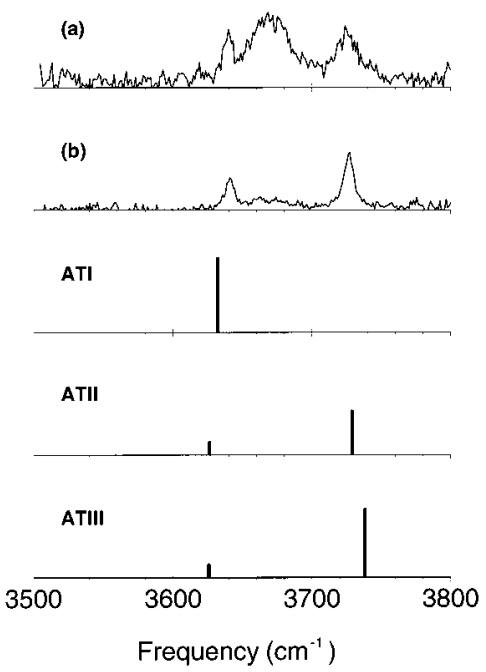

Figure 7. Vibrational predissociation spectra of $\mathrm{H}^{+}\left[\left(\mathrm{CH}_{3}\right)_{2} \mathrm{CO}\right]_{2}\left(\mathrm{H}_{2} \mathrm{O}\right)$ synthesized using a room-temperature nozzle with a backing pressure of (a) 50 and (b) 200 Torr. Shown underneath are the DFT-calculated stick diagrams of isomers ATI, ATII, and ATIII. The dramatic temperature dependence of the spectra indicates the presence of more than one stable isomer in the supersonic jet.
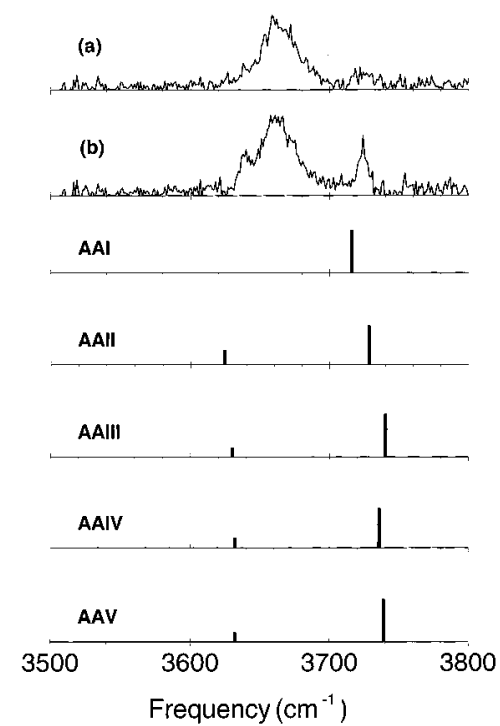

Figure 8. Vibrational predissociation spectra of $\mathrm{H}^{+}\left[\left(\mathrm{CH}_{3}\right) \mathrm{HCO}\right]_{2}\left(\mathrm{H}_{2} \mathrm{O}\right)$ synthesized using a room-temperature nozzle with a backing pressure of (a) 150 and (b) 250 Torr. Shown underneath are the DFT-calculated stick diagrams of isomers AAI, AAII, AAIII, AAIV, and AAV. The dramatic temperature dependence of the spectra indicates the presence of more than one stable isomer in the supersonic jet.

2. Similar to those of the ether analogues, the $\mathrm{CH}$ stretching absorption bands of the keto dimers are too weak to provide useful structural information.

\section{Discussion}

A. Structural Isomerization. Dependence of the vibrational predissociation spectra on beam temperature is dramatic for all hydrophobe-containing water clusters presently investigated. However, this dramatic temperature dependence is not directly connected to a drastic change in population of the two isomeric forms, since the observed band intensities in these action spectra are folded with the dissociation probability of the vibrationally excited cluster isomers. Considering $\mathrm{H}^{+}\left[\left(\mathrm{CH}_{3}\right)_{2} \mathrm{O}\right]_{2}\left(\mathrm{H}_{2} \mathrm{O}\right)$ as an example, both the ab initio calculations and thermochemical measurements ${ }^{25}$ indicate that isomer MMEI should be the
ATI

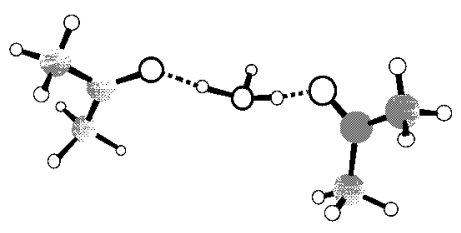

ATII
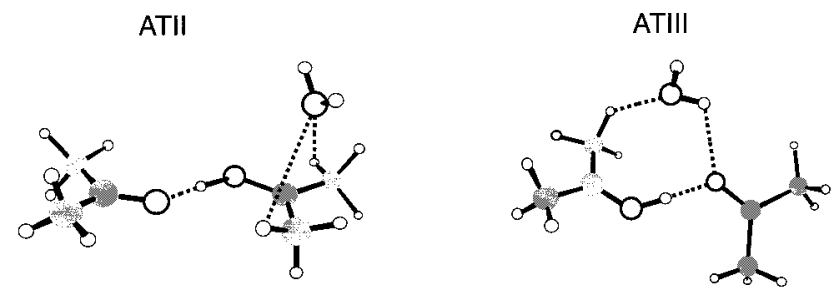

Figure 9. DFT-optimized structures of $\mathrm{H}^{+}\left[\left(\mathrm{CH}_{3}\right)_{2} \mathrm{CO}\right]_{2}\left(\mathrm{H}_{2} \mathrm{O}\right)$ isomers. The $\mathrm{C}, \mathrm{O}$, and $\mathrm{H}$ atoms are denoted by gray solid, large open and small open circles, respectively.<smiles>CC(OOC(=O)OOC(=O)O)C(C)(C)O</smiles>

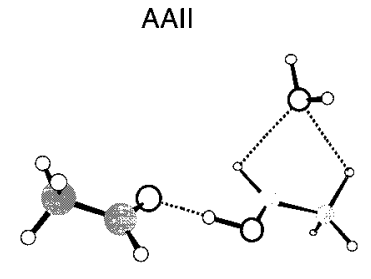

AAIV<smiles>O=P(O)(O)OOOP(O)OOO</smiles>

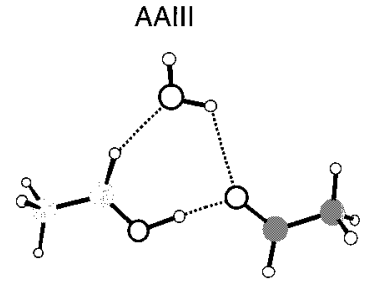

AAV

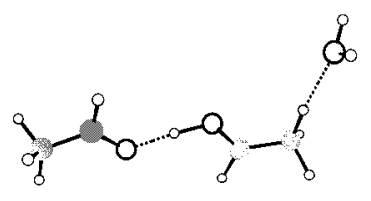

Figure 10. DFT-optimized structures of $\mathrm{H}^{+}\left[\left(\mathrm{CH}_{3}\right) \mathrm{HCO}_{2}\left(\mathrm{H}_{2} \mathrm{O}\right)\right.$ isomers. The $\mathrm{C}, \mathrm{O}$, and $\mathrm{H}$ atoms are denoted by gray solid, large open and small open circles, respectively.

thermodynamically more stable form. Initially, this stands in contradiction to our observations (cf. Figure 1) that the band intensity of the free-OH stretches of MMEI (MMEII) diminishes (increases) as the cluster temperature decreases. ${ }^{18}$ One, however, can understand this surprising observation in terms of clustering kinetics together with the dissociation probability of each isomer as follows.

According to the thermochemical measurements [eqs 4 and $5],{ }^{25}$ the clustering of $\left[\left(\mathrm{CH}_{3}\right)_{2} \mathrm{O}\right]_{2} \mathrm{H}^{+}$is energetically favored over $\left(\mathrm{CH}_{3}\right)_{2} \mathrm{OH}^{+}-\mathrm{H}_{2} \mathrm{O}$ upon supersonic expansion. Loose association of $\mathrm{H}_{2} \mathrm{O}$ with $\left[\left(\mathrm{CH}_{3}\right)_{2} \mathrm{O}\right]_{2} \mathrm{H}^{+}$can follow to form MMEII. To convert MMEII to the energetically more favored isomer MMEI, a structural isomerization barrier must be overcome. Ab initio calculations indicate that this barrier has a height slightly higher than the dissociation barrier leading to the products $\left[\left(\mathrm{CH}_{3}\right)_{2} \mathrm{O}\right]_{2} \mathrm{H}^{+}$and $\mathrm{H}_{2} \mathrm{O} .{ }^{37} \mathrm{~A}$ cartoon of the calculated potential energy surface for this isomerization process is depicted in Figure 11. It contains a transition state, with a four-membered ring geometry, lying $\sim 1.3 \mathrm{kcal} / \mathrm{mol}$ above 


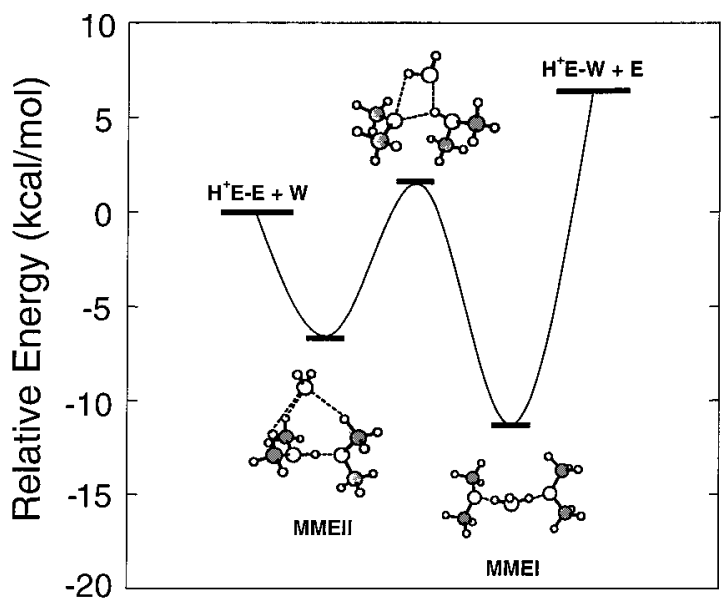

Reaction Coordinate

Figure 11. Potential energy diagram of $\mathrm{H}^{+}\left[\left(\mathrm{CH}_{3}\right)_{2} \mathrm{O}\right]_{2}\left(\mathrm{H}_{2} \mathrm{O}\right)$. The transition state is calculated to be $1.3 \mathrm{kcal} / \mathrm{mol}$ higher in total energy than that of $\left(\mathrm{CH}_{3}\right)_{2} \mathrm{O}-\mathrm{H}^{+}-\mathrm{O}\left(\mathrm{CH}_{3}\right)_{2}$ and $\mathrm{H}_{2} \mathrm{O}$ (denoted as $\mathrm{H}^{+} \mathrm{E}-\mathrm{E}+$ W) and is $5.1 \mathrm{kcal} / \mathrm{mol}$ lower than that of $\left(\mathrm{CH}_{3}\right)_{2} \mathrm{O}-\mathrm{H}^{+}-\mathrm{OH}_{2}$ and $\left(\mathrm{CH}_{3}\right)_{2} \mathrm{O}$ (denoted as $\mathrm{H}^{+} \mathrm{E}-\mathrm{W}+\mathrm{E}$ ). Hence, the calculated total interaction energy of the clustering, $\left(\mathrm{CH}_{3}\right)_{2} \mathrm{OH}^{+}-\mathrm{H}_{2} \mathrm{O}+\left(\mathrm{CH}_{3}\right)_{2} \mathrm{O} \rightarrow$ $\mathrm{H}_{3} \mathrm{O}^{+}\left[\left(\mathrm{CH}_{3}\right)_{2} \mathrm{O}\right]_{2}$, is $\Delta E=-17.7 \mathrm{kcal} / \mathrm{mol}$.

$\left[\left(\mathrm{CH}_{3}\right)_{2} \mathrm{O}\right]_{2} \mathrm{H}^{+}$and $\mathrm{H}_{2} \mathrm{O}$. As predicted by this calculation, some internal energies are required for the clusters to overcome the isomerization barrier to form the hydronium-centered isomer. Otherwise, they can be easily trapped in the MMEII configuration.

A second factor, which also contributes to the intensity anomaly in Figure 1, is the dissociation probability. This factor is particularly important in the case when the cluster ions are generated with a sufficient amount of internal energy to populate both the MMEI and MMEII states. We have previously demonstrated that the vibrationally induced dissociations involved in this experiment are predominantly one-photon processes. ${ }^{18}$ The presence of excess internal energies allows the dissociation to occur upon excitation of the clusters at 3300$3800 \mathrm{~cm}^{-1}(h v=9-11 \mathrm{kcal} / \mathrm{mol})$. A simple estimation based on the harmonic oscillator approximation for all the DFTcalcualted vibrational modes suggests that isomers MMEI and MMWII contain an internal energy of 2.7 and $2.9 \mathrm{kcal} / \mathrm{mol}$, respectively, at $170 \mathrm{~K}$. Since inducing the unimolecular loss of water in MMEI requires an energy of $16.3 \mathrm{kcal} / \mathrm{mol}$ (according to the measurement), ${ }^{25}$ a large portion of such vibrationally excited molecules cannot dissociate. As the content of internal energy (and so the effective dissociation probability) decreases with cluster temperature, the spectral features of MMEI diminish correspondingly at a lower temperature. The behavior notably differs from that of isomer MMEII, which is held together by the proton-enhanced hydrophobic force with a $\Delta H^{\circ}$ D of $6 \mathrm{kcal} /$ mol. Since the supply of internal energy is not needed to break these multiple $-\mathrm{C}-\mathrm{H} \cdots \mathrm{O}-$ bonds, the dissociation probability of this hydrophobic isomer is always unity, independent of cluster temperature.

The large difference $(\sim 7 \mathrm{kcal} / \mathrm{mol})$ in dissociation energy between the hydronium-centered and the hydrophobic isomers leads to the suggestion that they may substantially differ in cluster temperature upon the investigation. While both isomers are created under the same supersonic expansion conditions, the latter is expected to be colder, since evaporative cooling can promote it more effectively to a lower temperature state, namely, lower than $170 \mathrm{~K}$. The expectation is indeed in accord with our bandwidth measurements in Table 2 that the free-OH stretching absorption bands of the hydrophobic isomers are always narrower than those of the hydronium-centered counterparts by roughly a factor of 2 .

B. Spectral Frequency Shifts. A close comparison of the vibrational predissociation spectra of $\mathrm{H}^{+}\left[\left(\mathrm{CH}_{3}\right)_{2} \mathrm{O}_{2}\left(\mathrm{H}_{2} \mathrm{O}\right)\right.$ and $\mathrm{H}^{+}\left[\left(\mathrm{C}_{2} \mathrm{H}_{5}\right) \mathrm{O}\right]_{2}\left(\mathrm{H}_{2} \mathrm{O}\right)$ reveal a significant difference in band position of the free- $\mathrm{OH}$ stretches of the hydrophobic isomers. In $\left[\left(\mathrm{CH}_{3}\right)_{2} \mathrm{O}\right]_{2} \mathrm{H}^{+}-\mathrm{H}_{2} \mathrm{O}$, both the symmetric and asymmetric stretching frequencies are red-shifted from those of $\left[\left(\mathrm{CH}_{3}\right)\right.$ $\left.\left(\mathrm{C}_{2} \mathrm{H}_{5}\right) \mathrm{O}\right]_{2} \mathrm{H}^{+}-\mathrm{H}_{2} \mathrm{O}$ by $4 \mathrm{~cm}^{-1}$. This frequency shifting is regular and significant and appears to correlate well with the conclusion reached by solution-phase studies ${ }^{13}$ that ethyl groups are more hydrophobic than methyl groups. It implies that the magnitude of the frequency red shifts can be used as a direct measure for the hydrophobicity of hydrocarbon groups. For these two hydrophobic clusters, a simple Mulliken population analysis ${ }^{37}$ of atomic charges indicates that the positive charge originating from the proton is spread over the entire ether dimers and, as a result of the charge rearrangement, ${ }^{12}$ the hydrogen atoms involved in the hydrogen bonding carry more positive charge than the remaining hydrocarbon hydrogen atoms. The atomic charges on the excess proton in MMEII and MEEII are +0.639 and +0.645 , respectively.

Additional important information conveyed by the frequency red shifts is the multiple hydrogen bond formation in these hydrophobic isomers. In our recent studies of $\mathrm{H}^{+}\left(\mathrm{H}_{2} \mathrm{O}\right)_{n}$ and $\mathrm{NH}_{4}{ }^{+}\left(\mathrm{H}_{2} \mathrm{O}\right)_{n}$ clusters, ${ }^{18,34}$ we found that the frequencies of the free- $\mathrm{OH}$ stretches of proton-accepting $\mathrm{H}_{2} \mathrm{O}$ are sensitive to the number of hydrogen bonds involved. Since the solvent water molecules are linked to the protonated ion core (either $\mathrm{H}_{3} \mathrm{O}^{+}$ or $\mathrm{NH}_{4}{ }^{+}$) through single hydrogen bonds with $\Delta H^{\circ}{ }_{\mathrm{D}}=10-13$ $\mathrm{kcal} / \mathrm{mol}$, their symmetric and asymmetric stretching frequencies fall within the range $3640-3650$ and $3730-3740 \mathrm{~cm}^{-1}$, respectively. ${ }^{18,19,36}$ However, as the water molecule behaves like a double proton acceptor in a four-membered ring in $\mathrm{NH}_{4}{ }^{+}$$\left(\mathrm{H}_{2} \mathrm{O}\right)_{5}$, the frequencies of the two free-OH stretching modes are red-shifted to 3631 and $3714 \mathrm{~cm}^{-1}$. Furthermore, the absorption bands become narrower since the orientation of this double-proton-accepting $\mathrm{H}_{2} \mathrm{O}$ is fixed in space. ${ }^{18}$ In all the hydrophobic clusters presently investigated, the $\mathrm{OH}$ vibrational features are relatively sharp, with an average bandwidth of $9 \pm$ $4 \mathrm{~cm}^{-1}$ and typical resonant frequencies of $3638 \pm 2$ and 3723 $\pm 3 \mathrm{~cm}^{-1}$ (Table 2). The frequencies are all significantly lower than that of the single-proton-accepting water in $\mathrm{H}^{+}\left(\mathrm{H}_{2} \mathrm{O}\right)_{n}$, $\mathrm{NH}_{4}{ }^{+}\left(\mathrm{H}_{2} \mathrm{O}\right)_{n}$, and other water-associated clusters. ${ }^{36}$ A reasonable interpretation for this difference is that the solvent water molecules in these hydrophobic isomers are all bound to the protonated hydrophobes through multiple hydrogen bonds, a picture in accord with the result of the DFT calculations.

C. Various Hydration Sites. An alkyl group can interact with the solvent water molecule in a variety of ways. This is readily demonstrated by the calculations for $\mathrm{H}^{+}\left[\left(\mathrm{CH}_{3}\right)\left(\mathrm{C}_{2} \mathrm{H}_{5}\right) \mathrm{O}_{2} 2^{-}\right.$ $\left(\mathrm{H}_{2} \mathrm{O}\right)$, where two structurally similar hydrophobic isomers are found. In isomer MMEII, the linkage between $\left[\left(\mathrm{CH}_{3}\right)_{2} \mathrm{O}\right]_{2} \mathrm{H}^{+}$ and $\mathrm{H}_{2} \mathrm{O}$ is established by three hydrogen bonds involving three separate methyl groups, whereas it is the binding of $\mathrm{H}_{2} \mathrm{O}$ with the $\mathrm{H}$ atoms in the methylene groups that stabilizes MEEII. One can expect the pattern of the interactions to vary sensitively with the electronic structures of the hydrophobes. Indeed, considerably more hydrophobic isomers are predicted to exist for keto-containing water clusters, which adopt a less compact structure, and the excess proton is more accessible by the water molecule than in their protonated ether analogues.

The DFT-based calculations forecast that at least three isomers 
can exist for $\mathrm{H}^{+}\left[\left(\mathrm{CH}_{3}\right)_{2} \mathrm{CO}_{2}\left(\mathrm{H}_{2} \mathrm{O}\right)\right.$, as depicted in Figure 9. Among them, the hydrophobic isomer ATII is the second lowest in energy and is less strongly bound than the $\mathrm{H}_{3} \mathrm{O}^{+}$-centered ATI by $4.2 \mathrm{kcal} / \mathrm{mol}$. Notably, the strength of this bonding $\left(\Delta H_{\mathrm{D}}\right.$ $=5.8 \mathrm{kcal} / \mathrm{mol}$ ) is comparable to that of MMEII and MEEII, despite the water molecule being situated exclusively on one side of the acetone monomer unit and being linked to the ion core by only two ionic hydrophobic bonds. The DFT calculations also found the third isomer ATIII, which has a bridged structure with one of the two $\mathrm{H}$ atoms of the water molecule attached to the carbonyl group of the acetone, forming a ring. This structure is the least energetically favored $(\sim 2 \mathrm{kcal} / \mathrm{mol}$ higher than that of ATII) among the three isomers. Figure 7 compares the DFT-calculated stick spectra between them. A combination of the energetics and frequency calculations leads to assignments (Table 2) of the spectra to isomers ATI and ATII, which are the dominant species in the supersonic expansion.

In an attempt to search for a structure with the excess proton shared by three ligands in $\mathrm{H}^{+}\left[\left(\mathrm{CH}_{3}\right)_{2} \mathrm{CO}\right]_{2}\left(\mathrm{H}_{2} \mathrm{O}\right)$, the computation collapsed to ATIII. It is concluded from this computational attempt that sharing the excess proton by more than two ligands is energetically unfavored, although it appears geometrically possible. Such a behavior stands as an interesting contrast to that of metallic ion solvation, where a coordination of six water molecules has been theoretically predicted ${ }^{38}$ and experimentally explored for $\mathrm{Cs}^{+}$in particular. ${ }^{39} \mathrm{We}$ attribute this sharp contrast to the tiny size of the proton, which is a point charge and essentially dimensionless.

A replacement of the methyl groups in $\left[\left(\mathrm{CH}_{3}\right)_{2} \mathrm{CO}_{2} \mathrm{H}^{+}-\mathrm{H}_{2} \mathrm{O}\right.$ by hydrogen atoms reduces the symmetry of the hydrophobe and subsequently increases the complexity of the structural isomerization. In this cluster, both cis and trans isomeric forms can exist owing to the presence of the $-\mathrm{C}=\mathrm{O} \cdots$ double bonds. ${ }^{40}$ Figure 10 depicts the theoretically predicted structures of four $\left[\left(\mathrm{CH}_{3}\right) \mathrm{HCO}\right]_{2} \mathrm{H}^{+}-\mathrm{H}_{2} \mathrm{O}$ isomers that are close in interaction energy of $\pm 1 \mathrm{kcal} / \mathrm{mol}$. Among them, isomers AAII and AAIII are structurally analogous to ATII and ATIII, and the trans forms of the protonated acetaldehyde dimer are significantly more stable than the cis forms in all cases. A noteworthy feature in isomers AAIV and AAV is that the linkage between $\left[\left(\mathrm{CH}_{3}\right)\right.$ $\mathrm{HCO}_{2} \mathrm{H}^{+}$and $\mathrm{H}_{2} \mathrm{O}$ involves only single hydrogen bonds. These charge-enhanced $-\mathrm{C}-\mathrm{H} \cdots \mathrm{O}-$ bonds are not only directional but also strong, with a calculated total interaction energy of -6.6 and $-4.2 \mathrm{kcal} / \mathrm{mol}$ for AAIV and AAV, respectively. Also as a result of partial charge transfer in the directional hydrogen bonding (Figure 10), the oscillator strength of the bonded-CH stretching vibration is substantially enhanced, up to a factor of $5 .{ }^{37} \mathrm{We}$ have attempted to search for these unusual features in the frequency region around $3000 \mathrm{~cm}^{-1}$ but failed to find any noticeable absorptions using the present apparatus. The failure can be due to either of the two possibilities that the absorption bands are too broad or that such hydrogen-bonded isomers are too low in relative abundance. It awaits further improvement of our detection sensitivity to obtain the spectra of these hydrophobic cluster isomers. Cooling the cluster ions by adding spectator molecules ${ }^{41}$ like $\mathrm{H}_{2}$ or Ar to the interrogated species can also be attempted in future experiments.

\section{Conclusion and Outlook}

The presently engaged research systematically tackles the fundamental issue concerning the hydrophobicity of saturated hydrocarbon groups $\left(-\mathrm{H},-\mathrm{CH}_{3}\right.$, and $\left.-\mathrm{C}_{2} \mathrm{H}_{5}\right)$ in the presence of charges. Four representative cluster ions, $\left[\left(\mathrm{CH}_{3}\right)_{2} \mathrm{O}\right]_{2} \mathrm{H}^{+-}$ $\mathrm{H}_{2} \mathrm{O},\left[\left(\mathrm{CH}_{3}\right)\left(\mathrm{C}_{2} \mathrm{H}_{5}\right) \mathrm{O}-\mathrm{H}^{+}-\mathrm{O}\left(\mathrm{CH}_{3}\right)\left(\mathrm{C}_{2} \mathrm{H}_{5}\right)\right]-\mathrm{H}_{2} \mathrm{O},\left[\left(\mathrm{CH}_{3}\right)_{2} \mathrm{CO}-\right.$
$\left.\mathrm{H}^{+}-\mathrm{OC}\left(\mathrm{CH}_{3}\right)_{2}\right]-\mathrm{H}_{2} \mathrm{O}$, and $\left[\left(\mathrm{CH}_{3}\right) \mathrm{HCO}-\mathrm{H}^{+}-\mathrm{OCH}\left(\mathrm{CH}_{3}\right)\right]-$ $\mathrm{H}_{2} \mathrm{O}$, have been thoroughly studied both theoretically and experimentally. They share the common feature in chargesupported hydrophobic interactions of the type $-\mathrm{C}-\mathrm{H} \cdots \mathrm{O}-$, which distinctly differ from conventional hydrogen bonding. From the diverse interaction patterns displayed by these clusters, it is suggested that they may serve as model molecules for a better understanding of the hydration of charged hydrophobic sites in biomolecules.

A natural choice of the species for future study is the use of charged amino acids and peptides as the ion cores. Studying the microsolvation of solitary amino acid molecules may provide an alternative means to measure the hydrophobicity of amino acid side chains, which has been mostly performed in bulk solution phases. ${ }^{15,16} \mathrm{~A}$ new definition ${ }^{42}$ of hydrophobicity is possible to be derived from the spectroscopic measurements of these gas-phase clusters.

Acknowledgment. We thank the Academia Sinica and the National Science Council (Grant No. NSC 89-2113-M-001-036CT) of Taiwan, the Republic of China, for financial support. We also thank Prof. Y. T. Lee for many useful discussions.

\section{References and Notes}

(1) See the special issue: Acc. Chem. Res. 1998, 31.

(2) Buckingham, A. D., Legon, A. C., Roberts, S. M., Eds.; Principles of Molecular Recognition; Blackie Academic \& Professional: New York, 1993.

(3) Ulman, A. An Introduction to Ultrathin Organic Films; Academic Press: Boston, 1991.

(4) Blokzijl, W.; Engberts, J. B. F. N. Angew. Chem., Int. Ed. Engl. 1993, 32, 1545. Hummer, G.; Garde, S.; Garcia, A. E.; Paulaitis, M. E. Pratt, L. R. J. Phys. Chem. B 1998, 102, 10469.

(5) Novick, S. E. In Structure and Dynamics of Weakly Bound Molecular Complexes; Weber, A., Ed.; Reidel: Dordrecht, 1987. Novick, S. E.; Leopold, K. R.; Klemperer, W. In Atomic and Molecular Clusters; Bernstein, E. R., Ed.; Elsevier: Amsterdam, 1990.

(6) Dore, L.; Cohen, R. C.; Schmuttenmaer, C. A.; Busarow, K. L.; Elrod, M. J.; Loeser, J. G.; Saykally, R. J. J. Chem. Phys. 1994, 100, 863. (7) Suenram, R. D.; Fraser, G. T.; Lovas, F. J.; Kawashima, Y. J. Chem. Phys. 1994, 101, 7230.

(8) Smith, D. E.; Haymet, A. D. J. J. Chem. Phys. 1993, 98, 6445 2703.

(9) Curtiss, L. A.; Frurip, D. J.; Blander, M. J. Chem. Phys. 1979, 71

(10) Steyert, D. W.; Elrod, M. J.; Saykally, R. J. J. Chem. Phys. 1993, 99, 7431. Steyert, D. W.; Elrod, M. J.; Saykally, R. J.; Suenram, R. D.; Lovas, F. J. J. Chem. Phys. 1993, 99, 7424.

(11) Peterson, K. I.; Klemperer, W. J. Chem. Phys. 1984, 81, 3842. Block, P. A.; Marshall, M. D.; Pedersen, L. G.; Miller, R. E. J. Chem. Phys. 1992, 96, 7321

(12) Meot-Ner, M.; Deakyne, C. A. J. Am. Chem. Soc. 1985, 107, 469.

(13) Sharp, K. A.; Nicholls, A.; Fine, R. F.; Honig, B. Science 1991, $252,106$.

(14) Mancera, R. L.; Buckingham, A. D. J. Phys. Chem. 1995, 99, 14632. Luzar, A. Faraday Discuss. 1996, 103, 29. Martorana, V.; Bulone, D.; San Biagio, P. L.; Palma-Vittorelli, M. B.; Palma, M. U. Biophys. J. 1997, 73, 31. Lynden-Bell, R. M.; Rasaiah, J. C. J. Chem. Phys. 1997, 107, 1981.

(15) Hecht, D.; Tadesse, L.; Walters, L. J. Am. Chem. Soc. 1993, 115, 3336.

(16) Ide, M.; Maeda, Y.; Kitano, H. J. Phys. Chem. B 1997, 101, 7022.

(17) Gill, S. J.; Dec, S. F.; Olofsson, G.; Wadso, I. J. Phys. Chem. 1985, $89,3758$.

(18) Wang, Y.-S.; Chang, H.-C.; Jiang, J. C.; Lin, S. H.; Lee, Y. T.; Chang, H.-C. J. Am. Chem. Soc. 1998, 120, 8777. Chang, H.-C.; Wang, Y.-S.; Lee, Y. T.; Chang, H.-C. Int. J. Mass Spectrom. 1998, 179/180, 91.

(19) Chang, H.-C.; Jiang, J. C.; Hahndorf, I.; Lin, S. H.; Lee, Y. T.; Chang, H.-C. J. Am. Chem. Soc. 1999, 121, 4443.

(20) GAUSSIAN 94, revision D.3; Gaussian, Inc.: Pittsburgh, PA, 1995.

(21) Gruenloh, C. J.; Carney, J. R.; Arrington, C. A.; Zwier, T. S.; Fredericks, S. Y.; Jordan, K. D. Science 1997, 276, 1678.

(22) Jiang, J. C.; Chang, H.-C.; Lee, Y. T.; Lin, S. H. J. Phys. Chem. A 1999, 103, 3123.

(23) Boys, S. F.; Bernardi, F. Mol. Phys. 1970, 19, 553. 
(24) Wang, Y.-S.; Jiang, J. C.; Cheng, C.-L.; Lin, S. H.; Lee, Y. T.; Chang, H.-C. J. Chem. Phys. 1997, 107, 9695. Jiang, J. C.; Chang, J. C. Wang, B.-C.; Lin, S. H.; Lee, Y. T.; Chang, H.-C. Chem. Phys. Lett. 1998, $289,373$.

(25) Grimsrud, E. P.; Kebarle, P. J. Am. Chem. Soc. 1973, 95, 7939. Hiraoka, K.; Grimsrud, E. P.; Kebarle, P. J. Am. Chem. Soc. 1974, 96, 3359. Hiraoka, K.; Kebarle, P. J. Am. Chem. Soc. 1976, 98, 6119.

(26) Hunter, E. P. L.; Lias, S. G. J. Phys. Chem. Ref. Data 1998, 27, 413.

(27) Meot-Ner, M.; Speller, C. V. J. Phys. Chem. 1986, 90, 6616.

(28) Graul, S. T.; Squires, R. R. Int. J. Mass Spectrom. Ion Processes 1989, 94,41 .

(29) Schindler, T.; Berg, C.; Niedner-Schatteburg, G.; Bondybey, V. E. Chem. Phys. Lett. 1995, 201, 491.

(30) Hirao, K.; Sano, M.; Yamabe, S. Chem. Phys. Lett. 1982, 87, 181.

(31) Lifshitz, C.; Iraqi, M.; Peres, T. Rapid Commun. Mass Spectrom. 1990, 4, 485. Aviyente, V.; Iraqi, M.; Peres, T.; Lifshitz, C. J. Am. Chem. Mass Spectrom. 1991, 2, 113. Wei, S.; Tzeng, W. B.; Keesee, R. G.; Castleman, A. W., Jr. J. Am. Chem. Soc. 1991, 113, 1960.

(32) Meot-Ner, M.; Scheiner, S.; Yu, W. O. J. Am. Chem. Soc. 1998 120,6980 .

(33) Yeh, L. I.; Okumura, M.; Myers, J. D.; Price, J. M.; Lee, Y. T. J. Chem. Phys. 1989, 91, 7319.

(34) Chang, H.-C.; Jiang, J. C.; Wang, Y.-S.; Chang, H.-C.; Lin, S. H.; Lee, Y. T. J. Chin. Chem. Soc. 1999, 121, 4443. Jiang, J. C.; Wang, Y.-S.;
Chang, H.-C.; Lin, S. H.; Lee, Y. T.; Niedner-Schatteburg, G.; Chang, H.C. J. Am. Chem. Soc., in press.

(35) Xantheas, S. S. J. Chem. Phys. 1995, 102, 4505.

(36) In addition to the monohydrate, we have also investigated the structure and spectroscopy of $\mathrm{H}^{+}\left[\left(\mathrm{CH}_{3}\right)_{2} \mathrm{O}_{2}\left(\mathrm{H}_{2} \mathrm{O}\right)_{2}\right.$. The spectra, however, display little temperature dependence; only two absorption bands corresponding to the symmetric and asymmetric stretches at 3647 and $3734 \mathrm{~cm}^{-1}$, respectively, are observed in the temperature range $150-200 \mathrm{~K}$. It indicates that the $\mathrm{H}_{3} \mathrm{O}^{+}$-centered structure with a completed first solvation shell should prevail in the supersonic expansion [Jiang, J. C.; Hahndorf, I.; Chang, H.C. Unpublished results.]. The observation is in accord with the DFT calculations, which predict that the $\mathrm{H}_{3} \mathrm{O}^{+}$-centered isomer is thermodynamically more stable than the hydrophobic ones by at least $10 \mathrm{kcal} / \mathrm{mol}$.

(37) Detailed calculations of the potential energy surface and the Mulliken population analysis will be presented in a separate publication.

(38) Probst, M. M.; Hermansson, K. J. Chem. Phys. 1992, 96, 8995 and references therein.

(39) Weinheimer, C. J.; Lisy, J. M. J. Chem. Phys. 1996, 105, 2938.

(40) Chu, C. H.; Ho, J. J. J. Phys. Chem. 1995, 99, 1151.

(41) Okumura, M.; Yeh, L. I.; Myers, J. D.; Lee, Y. T. J. Phys. Chem. 1990, 94, 3416. Ayotte, P.; Bailey, C. G.; Kim, J.; Johnson, M. A. J. Chem. Phys. 1998, 108, 444

(42) Hecht, D.; Tadesse, L.; Walters, L. J. Am. Chem. Soc. 1992, 114, 336. 